\title{
Pemberdayaan Desa Wisata Melalui Pengembangan Wisata Air Terjun Songgo Tuyo di Desa Nogosari Kec. Pacet Kabupaten Mojokerto
}

\author{
Imam Safii \\ Institut Pesantren KH.Abdul Chalim, \\ Mojokerto \\ E-mail: syafiikarim90@yahoo.com
}

\section{Ashad Abdillah Rosyid}

Institut Pesantren KH.Abdul Chalim, Mojokerto

E-mail:

\section{Hasyim Asy'ari}

Institut Pesantren KH.Abdul Chalim, Mojokerto

E-mail: hasyim.ikhac@gmail.com

\author{
Alfin Fatih \\ Institut Pesantren KH.Abdul Chalim, \\ Mojokerto \\ E-mail: alfin@gmail.com
}

\section{Article History:}

Received: 2019-10-16

Revised: 2020-01-17

Accepted: 2020-05-31

Keywords: Asset Based Approach (ABA),

Sustainable Forest Tourism, Village Empowerment

\begin{abstract}
Natural tourism assets are frequently driven by market forces where rich people make investment by collaborating with local government. It is rarely that the local community has the authorization to manage the assets by themselves, including the people in Nogosari village with its Songgo Tuyo waterfalls. This community service aimed at supporting and assisting the local people to optimize the available assets by themselves. Asset Based Approach (ABA) was employed by maximizing the promotion of the existing assets through the combination of online promotion and a photo competition in the tourism area. The programs was succesful in raising new enthusiasm from the community to develop the tourism resources not only the waterfalls but also the infrastructure, services, cultural, culinary, and merchandise, and attracted more tourists to come.
\end{abstract}


berkelanjutan (suistainable livelihood). Dengan adanya aset yang dimiliki oleh sebuah desa, Air terjun misalnya maka sudah saatnya dikembangkan ke arah perekonomian masyarakat dengan pengembangan desa dan wisata alam yang ada pada desa tersebut. ${ }^{2}$

Salah satu desa yang menjadi lokasi pengabdian ini adalah desa Nogosari. Desa Nogosari merupakan salah satu desa yang berada wilayah kecamatan Pacet kabupaten Mojokerto yang mayoritas masyarakat bermata pencaharian sebagai pedagang dan pertanian dengan karakter masyarakat desa yaitu sopan, beretika dan religius, jumlah penduduk yang terus bertambah dari tahun ke tahun sehingga merupakan daerah yang berpenduduk sangat padat mencapai 1.876 jiwa dengan tingkat pendidikan yang bervariasi mulai tamat SD sampai dengan perguruan tinggi, tingkat kesehatan masyarakat desa Nogosari cukup baik karena ditunjang dengan sarana dan prasarana yang belum memadai. Jarak desa Nogosari ke kantor kecamatan Pacet yang relatif jauh sehingga mempengaruhi pola dan tingkah laku masyarakat desa.

Mayoritas masyarakat bermata pencaharian pertanian/peternakan dan pedagang. Permasalahan yang sering muncul berkaitan dengan mata pencaharian penduduk adalah tersedianya lapangan pekerjaan yang kurang memadahi dengan perkembangan penduduk sebagaimana tertuang dalam perencanaan pembangunan daerah kabupaten Mojokerto.Hal lain yang perlu diperhatikan dalam pembangunan desa adalah melakukan usaha perluasan kesempatan kerja dengan melakukan penguatan usaha kecil, pemberian kredit sebagai modal untuk pengembangan usaha khususnya di bidang usaha kecil menengah.

Selanjutnya sebagai modal dasar pelaksanaan pembangunan di desa Nogosari sumber daya alam mutlak diperlukan untuk mendukung tercapainya program pembangunan desa yang direncanakan dengan baik. Berdasarkan hasil amtan bahwasanya di desa Nogosari ada beberapa aset, sumber daya alam yang dapat di berdayakan dijadikan sebagai sarana penopang perokomian masyarakat. Adapun sumber daya alam di desa Nogosari seperti halnya tabel dibawah ini :

Tabel 1. Daftar Sumber Daya Alam di Desa Nogosari ${ }^{3}$

\begin{tabular}{clcc}
\hline No & Uraian Sumber Daya Alam & Volume & Satuan \\
\hline 1 & Lahan Persawahan & 199,038 & $\mathrm{Ha}$ \\
\hline 2 & Sumber Air & 4 & Mata Air \\
\hline 3 & Lahan Tegalan & 61 & $\mathrm{Ha}$ \\
\hline 4 & Sungai & 6.000 & $\mathrm{Meter}$ \\
\hline 5 & Tanaman; Padi, Jagung dan Palawija & 132 & $\mathrm{Ha}$ \\
\hline
\end{tabular}

2 Abdur Rozaki and Siti Rohaya, "Memberdayakan Desa Melalui Pariwisata Berbasis BUMDES ," Engagement: Jurnal Pengabdian Kepada Masyarakat 3, no. 1 SE-Articles (May 30, 2019), http://engagement.fkdp.or.id/index.php/engagement/article/view/46; Tular "Pengembangan Potensi Kepariwisataan Berbasis Masyarakat Di Desa Pengkol, Kabupaten Sukoharjo, Jawa Tengah," Bakti Budaya 1, no. 1 (2018): 73-91.

3 Diambil dari data desa Nogosari pada bulan 19 agustus tahun 2019. 
Berdasarkan paparan data di atas desa Nogosari tergolong salah satu desa yang mempunyai aset wisata Alam berupa aset Alam yang mengarah kepada pengairan dan salah satunya adalah Sungai. Sudah menjadi hal yang lumrah bahwa aset yang ada di desa seperti halnya pantai, distinasi desa serta beberapa aset lain yang menjadi penggerak utamya dari aset tersebut adalah adanya kekuatan pasar (market driven) ${ }^{4}$ dimana mereka (orang-orang yang mempunyai modal) melakukan politisasi permodalan melalui investasi dengan melakukan kolaborasi dengan pemerintah daerah setempat. Adanya penguasaan terhadap lahan serta distinasi yang dikelola oleh mereka (orang-orang yang mempunyai modal) dengan secara ekslusif. Maka kalau kita telaah pendekatan seperti ini hanya akan memperkaya dan memperkuat para pemilik modal. Jalan yang selalu mereka tempuh yaitu dengan pola patron-klien, para investor menjadi patron sebab mereka adalah sang pemilik modal sedangkan warga setempat menjadi klien yaitu berperan sebagai kuli dalam kegiatan parawisata. Peristiwa seperti ini merupakan hal yang lumrah terjadi di masyarakat kita khususnya pada sebuah lokasi tempat parawisata seperti halnya yang terjadi di Bali, Lombok serta beberapa tempat lain yang ada di Indonesia. Terkait fenomena ini Alison Mathie dan Gord Cunningham memberikan wacana bahwa pola relasi patron-klien tidak seyogyanya di praktikkan di tengah masyarakat yang mempunyai aset wisata, namun adanya semangat kewargaan, dimana adanya pembangunan yang digerakkan oleh komunitas warga (community driven development $)^{5}$ menjadi hal harus digalakkan di era saat ini.

Ketika membaca fenomena di atas terkait adanya pembangunan yang digerakkan oleh komunitas maka kesadaran warga akan aset yang mereka miliki perlu dihidupkan kembali. Pengembangan aset wisata yang digerakkan oleh warga ini sebagai modal dasar pelaksanaan pembangunan di sebuah desa sumber daya alam mutlak diperlukan untuk mendukung tercapainya program pembangunan desa yang direncanakan dengan baik. Terkait hal ini salah satunya adalah distinasi wisata desa yang ada di dusun Bulak kunci tepatnya di desa Nogosari kecamatan Pacet, Mojokerto. Salah satu distinasi wisata desa di dusun ini adalah wisata alam yang ada di desa ini. Adapun wisata yang terdapat di Bulakunci ialah air terjun yang masih terlihat sangat asri. Air terjun ini diberi nama Air Terjun Songgo Tuyo. Pada tiga tahun yang lalu, dusun Bulakunci di datangi dengan para pengunjung yang ingin berwisata ke Rimba Lestari. Akan tetapi, dikarenakan beberapa faktor yang tidak mendukung, Wisata Alam Rimba Lestari menjadi vakum. Sehingga membuat para pengunjung merosot pada tiga tahun terakhir sebelumnya.

Berdasarkan hasil observasi awal bahwasanya adanya kondisi yang sangat memperhatinkan akan eksistensi dari wisata air terjun Songgo Tuyo yang ada di dusun Bulakkunci ini. Wisata alam rimba lestari ini sudah memiliki beberapa spot foto yang

${ }^{4}$ David W Cravens, "Implementation Strategies in the Market-Driven Strategy Era," Journal of the Academy of Marketing Science 26, no. 3 (1998): 237-241.

5 Alison Mathie and Gord Cunningham, "From Clients to Citizens: Asset-Based Community Development as a Strategy for Community-Driven Development," Development in practice 13, no. 5 (2003): 474-486. 
menarik tetapi dikarenakan sudah lama vakum dan tidak terjaga kelestarianya dikarenakan tidak adanya dukungan dari lapisan masyarakat-struktur masyarakat dusun Bulakkunci maka semua spot foto tersebut sudah mulai banyak yang rusak. Selain itu, beberapa fasilitas lainnya juga terlihat using. Seperti musholla dan tempat duduk untuk bersantai. Kayu-kayu yang digunakan sebagai bahan utama fasilitas ini pun sudah rapuh, sehingga tidak layak untuk digunakan, jalan yang terbuat dari ban motor bekkas pun sudah sudah mulai banyak yang rusak. ${ }^{6}$ Wisata Air terjun Songgo Tuyo tentunya sangat berpotensi untuk dikembangkan menjadi wisata alam yang ada di desa Nogosari tepatnya dusun Bulakkunci selain itu hadirnya wisata ini bisa dijadikan sebagai sarana didalam menopang ekonomi masyarakat desa Nogosari dengan memberlakukan tiket masuk ke area air terjun Songgo Tuyo, serta mempersiakan lahan parkir untuk roda empat ataupun roda dua di area air terjun Songgo Tuyo, menjual minuman dan makanan di sekitar area air terjun Songgo Tuyo, menyiapakan sewa baju bagi para pengunjung yang akan mandi dan berselvi di area air terjun serta beberapa hal lain yang bisa dilakukan oleh warga sekitar demi lestarinya wisata alam serta penopang ekonomi masyarakat. Maka salah satu kendala yang masih dihadapi didalam pengembangan wisata ini adalah belum adanya kesadaran pada tataran warga masyarakat dusun Bulakkunci hingga strutur lapisan masyarakat akan potensi alam yang mereka miliki, selain itu belum adanya manajemmen yang maksimal didalam pengelolaan aset wisata Air Terjun Songgo Tuyo ini sehingga pengelolaanya hanya berjalan beberapa bulan saja dan sudah tidak berjalan lagi hingga saat ini.

Dari paparan di atas perlu kiranya langkah awal yang dilakukan didalam pengembangan aset wisata alam air terjun ini yaitu menciptakan kesadaran di antara komunitas warga serta menciptakan penguatan kelembagaan didalam mengelola wisata air terjun Songgo Toyo hingga harapan kedepan adalah wisata air terjun Songgo Toyo menjadi wisata alam yang ada di desa Nogosari dan tidak kalah dengan wisata-wisata lain yang di kecematan Pacet serti pemandian Air panas misalnya.

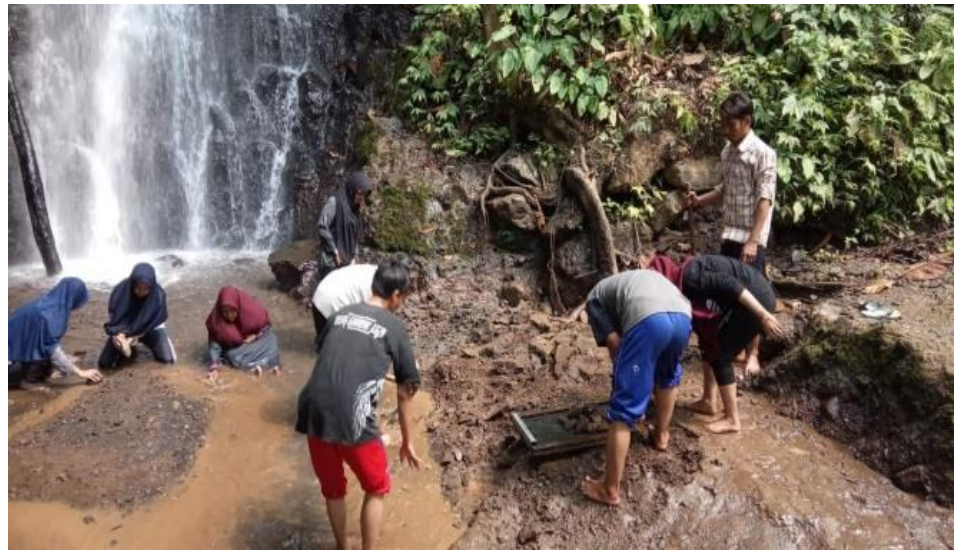

Gambar 1. Kondisi Air Terjun Songgo Tuyo yang memperhatinkan

${ }^{6}$ Hasil amatan awal di wisata air Terjun Songo Toyo 


\section{Metode}

Pengabdian yang dilaksanakan di desa Nogosari tepatnya di dusun Bulakkunci ini menggunkan strategi pendekatan dengan prinsip-prinsip dalam pengembangan masyarakat berbasis Asset Based Approach (ABA). Adapun poin utama dalam paradigma Asset Based Approach (ABA) bahwasanya semua ter-arahkan pada sebuah konteks pemahaman internalisasi adanya aset pada sebuah komunitas, masyarakat punya aset, masyarakat punya kekuatan dimana dengan adanya kekuatan yang dimiliki mereka (komunitas) mereka bisa menggerakkan serta mendayagunakan aset tersebut secara mandiri dan maksimal. ${ }^{7}$ Prinsip dalam paradigma ini mengisyaratkan kesadaran diri pada sebuah komunitas bahwasanya mereka punya kekuatan dan energi yang positif yang harus di identifikasikan, diketahuai, difahami, diinternalisasikan lalu kemudian dimobilisasi oleh masyarakat itu sendiri untuk menuju kesejahteraan serta keberdayaan adanya aset pada komunitas-masyarakat.

Kemitraan adalah model yang digunakan dalam pengabdian ini, hal ini dikarenakan kemitraan merupakan sebuah hubungan yang dibangun diantara indifidu atau kelompok yang didasarkan atas kerjasama serta tanggung jawab secara bersama didalam mencapai suatu tujuan yang ditarjetkan. Didalam prinsip Asset Based Approach (ABA) masyarakat dianggap mampu menemukan dan mengenali aset kekuatan serta potensi yang dimiliki mereka. Kkomunitas dipandang mampu menggerakkan serta memobilisasi diri mereka sendiri didalam melakukan perubahan sekaligus sebagai pelaku utama didalam terjadinya perubahan tersebut.

Maka oleh sebab itu sebuah upaya didalam meng identifikasi aset menjadi sebuah hal yang sangat penting. Pendekatan pengabdian berbasis aset ini seperti yang telah disebutkan dalam teori ABA, maka bisa di urai kepada lima lima jenis aset. Adapun yang pertama adalah sumber daya manusia. Manusia sebagai aset disini di asumsikan bahwa manusialah yang berpotensi didalam melakukan perubahan-perubahan pada sebuah komunitas. Manusia yang memiliki inesiatif, hal-hal yang inovatif demi perubahan bersama menjadi kunci utama didalam didalam terwujudnya sebuah perubahan dan kesejahteraan bersama pada sebuah komunitas. Selanjutnya yang kedua adalah aset alam. Adanya lingkungan bersih, kebun yang indah, pegunungan, air jernih, binatang dan lainnya yang berpotensi bisa dikembangkan demi memenuhi kebutuhan bersama dan kesejahteraan bersama.

Selanjutnya yang ketiga adalah berupa aset fisik, terkait aset ini bisa ditandai dengan adanya sarana transpotasi seperti jembatan, akses jalan yang mudah, gedunggedung serta beberapa tehnologi lain. Semakin banyaknya tersedia sarana prasarana

7 Anna. Paul Green, Garry and, Hanis, Asset Building Community Development (USA: Sage Publication, 2001); Nurdiyanah dkk, Panduan Pelatihan Dasar: Asset Based Community-Driven Development (ABCD) (Makasar: , Seri Publikasi Kemitraan Universitas - masyarakat UIN Alaudin Makkasar, Cetakan 1, 2016); UINSA KKN ABCD, Panduan KKN ABCD UIN Sunan Ampel Surabaya, Cetakan ke. (Surabaya: LP2M UIN Sunan Ampel Surabaya, 2015). 
sebgai aset fisik pada sebuah komunitas maka semakin potensi (daerah) akan berkembang. Keempat adalah sosial, hadirnya aset ini bisa dilihat dari beberapa kelompok, komunitas di masyarakat. Kelompok tahlilan misalnya, kelompok ibu-ibu PKK, kelompok ibu-ibu muslimat, asosiasi profesi, serta beberapa lembaga (institusi) di sebuah komunitas merupakan bagian dari aset sosial yang paling tiak dengan hadirnya aset ini menjadi sebuah ikon kolektif dari masyarakat. Selanjutnya yang kelima adalah aset ekonomi, aset yang terakhir ini bisa dilihat dari beberapa kegemaran di masyarakat, spirit rajin menabung misalnya, semangat berwirausaha. Berdasarkan kelima aset ini nantinya bisa dilihat dari aset mana saja yang menonjol pada sebuah komnitas kemudian menjadi skala prioritas dan dikembangkan secara bersama-sama demi kemaslahatan bersama, dari skala prioritas inilah nantinya komunitas sadar bahwa hal ini sangat penting sehinggaonset patren klien tak patut di praktikkan di daerah seperti halnya di dusun Bulakkunci. Mereka (komunitas) diharapkan sadar akan kekuatan yang mereka meliki agar terbebas dari belenggu (penjara) yang dikarenakan menghilangkan konsep kemitraan diantara mereka (komunitas).

Selanjutnya bukan menjadi keheranan bagi tim pendamping, kenapa kemudian menjadikan wisata air terjun Sunggo Tuyo ini menjadi sekala prioritas, tidak lain hal ini dikarenakan adanya rasa yang memprihatinkan akan keberadaan aset (wisata air terjun) yang sudah tidak lagi di manfaatkan dan sudah vakum beberapa tahun hingga saat ini. Oleh sebab itu kemuadian tim pendamping dan segenap dosen pendamping lapangan untuk kembali menghidupkan wisata ini dengan kembali menyadarkan warga akan aset yang mereka miliki dan perlu di hidupkan dan dikembangkan lagi, hingga nantinya menjadi sesuatu yang dapat memobilisasi mereka untuk semakin lebih maju serta menopang perekonomian warga dusnu bulak kunci.

\section{Tahap Pelaksanaan}

Setelah menggambarkan seputar metode yang digunakan dalam pengabdian ini maka selanjutnya tim pendamping mendiskripsikan tentang bagaimana tahap pelaksanaan dari metode Asset Based Approach (ABA) ini. Dalam pelaksanaannya metode ABA yang digunakan dalam pengabdian ini lebih mengarah pada appreciative inquiry dalam metode $\mathrm{ABCD}$. Kita ketahui bahwsanya penggunaan apresiatif inquiri dalam metode aba inilah yang menjadi poin utama didalam pengembangan aset yang ada pada sebuah komunitas. Diketahui bahwasanya berdasarkan penuturan masyarakat bahwa dusun Bulakkunci adalah dusun yang penuh dengan aset yang perlu dikembangkan untuk menunjang kehidupan menuju dusun mandiri dan salah satunya adalah wisata Air terjun. Berdasarkan metode ABA sebagai pendekatan dalam proses pengabdian ini maka disusun model pendekatan pendampingan komunitas sebagaimana dapat dilihat pada Gambar 2. 


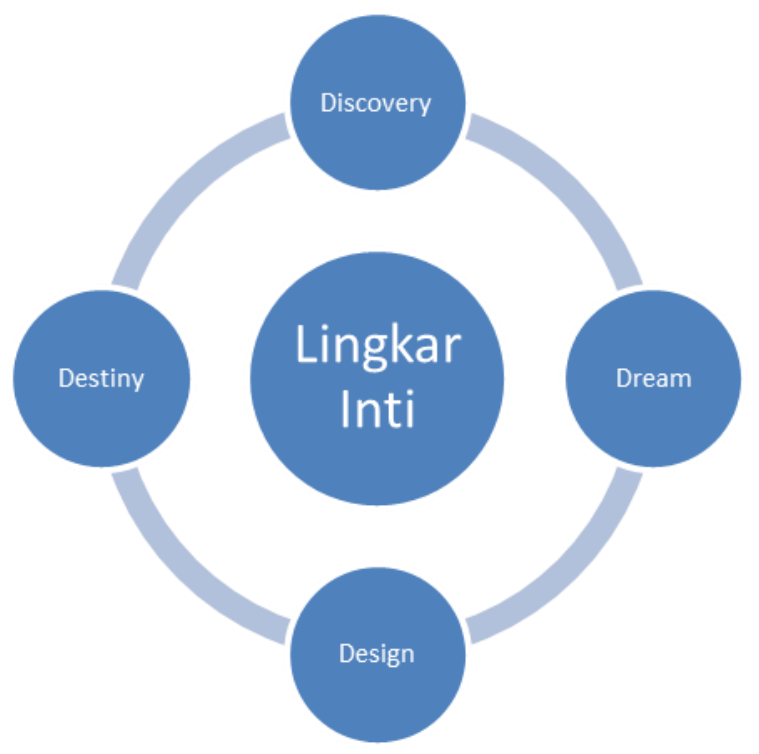

Gambar 2. Pendekatan ABCD dalam Pendampingan Komunitas

Adapun yang pertama dalam metode aba berdasrkan pengabdian ini adalah Discovery (penemuan), komunitas menggali aset yang ada didalam kehidupan mereka, bagaimana orang-orang sebelum mereka memanfaatkan serta aset yang hadir itu menjadi hal yang bermakna dalam kehidupan orang-orang sebelum mereka. Terkait hal ini tentunya nantik muncullah cerita dari mereka, kisah jatuh bangun kehidupan mereka dan succes story yang kemudian bisa dijadikan pengalaman yang berharga dari mereka (komunitas), ${ }^{8}$ dari cerita-cerita sukses mereka kemudian dicoba untuk diwujudkan kembali sebagai kekuatan mereka (komunitas) untuk dikembangkan demi kehidupan masa kini. Seperti halnya kisah tentang kecamatan Pacet adalah daerah yang dipenuhi dengan beberapa tempat wisata sebagai aset alam yang dimiliki seperti halnya pemandian air panas di kawasan wisara Trawas serta beberapa aset alam lain yang ada di kecamatan Pacet dan salah satunya adalah aset wisata alam yang ada di desa Nogosari tepatnya di dusun Bulakkunci yaitu wisata air terjun Songgo Tuyo.

Selain itu dusun inipun memeliki beberapa aset lain seperti halnya adanya tradisi lokal yang masih kuat pada tataran masyarakat seperti halnya budaya tahunan seperti budaya malam tirakatan yang dilaksanakan setiap satu tahun sekali dalam rangka memperingati malam kemerdekaan negara Indonesia. Selain itu juga ada beberapa warisan budaya masa lalu dalam masyarakat ini seperti seni Terbang Jidur yang biasanya dimainkan oleh grup Terbang Jidur ini tepatnya pada setiap hari selamatan desa yang dilakukan warga desa Nogosari. Selain itu sebagai kisah suksesnya dusun ini adanya semangat gotong royong yang sangat mengakar kuat pada kelompok masyarakat dusun Bulakkunci. Selanjunya terkait wisata alam rimba lestari yang juga pernah ada kisah-kisa sukses dari eksistensi keberadaan wisata alam rimba yang

8 Paul Green, Garry and, Hanis, Asset Building Community Development. 
dibabat bersama komponen masyarakat yaitu wisata air terjun Sonngo Tuyo. Wisata ini bisa dikatakan sukses sebab bisa kita lihat ada beberapa bukti fisik yang menopang kisah sukses dari wisata ini seperti adanya wisata ini pernah memiliki beberapa spot foto yang menarik ada fasilatas seperti musholla dan tempat duduk untuk bersantai. Kayu-kayu yang digunakan sebagai bahan utama untuk memperkenalkan wisata Alam rimba lestari kepada para wisatawan, adanya jalan (tangga) yang terbuat dari ban motor bekas menuju wisata alam ini. Namun semua ini hanya bagian dari kisah-kisah sukses pada tempo dulu wisata ini dan sudah harus di renovasi dan diperaiki.

Selanjutnya dalam pengabdian ini sebagai langkah metode ABA langkan selanjutnya yang kedua adalah dengan langkah dream (membangun mimpi). Pada tahapan ini adalah lebih mengarah kepada bagaimana komunitas membangun mimpi mereka menuju kehidupan yang lebih maju. Dalam hal ini komunitas diharapkan secara kolektif mampu membangun mimpi mereka, mereka (komunitas) telah punya skala prioritas dari skala prioritas inilah digerakkan oleh mereka secara bersama-sama menuju kemandirian ekonomi seperti halnya wisata yang ada didesa Nogosari dusun Bulakkunci. Terkait hal ini dimulai dari langkah yang paling kecil diantaranya komunitas mulai melakukan beberpa pertemuan yang dimulai dari kelompok ibu-ibu PKK, bapak-bapk jamaah Yasin Tahlil, Adek-adek karang taruna, serte beberapa kelompok yang ada di dusun Bulakkunci. Dari kelompok ini mereka (komunitas) memulai membersihkan menuju lokasi air terjun, selanjutnya mencoba memperbaiki beberapa spot foto yang sudah rusah, tempat shalat (Mushallah) yang sudah tidak layak, pakai, serta memberikan papan nama dengan tujuan mempermudah para wisatawan menuju arah wisata, dimana semua sarana-prasarana yang sebelumnya sudah pernah ada dan eksis pada tiga tahun sebelumnya oleh masyarakat dusun Bulak kunci.

Tahap selanjutnya adalah design (merencanakan), dalam hal ini terkait bagaimana komunitas membangun rencana dan langkah kongkrit menuju kemandirian ekonomi secara bersama pada sebuah komunitas. Ada juga yang mengatakan bahwasanya langkah yang ketiga ini adalah membangun kesepakatan bersama menuju aksi secara kolektif demi terwujudnya aset Alam berupa wisata alam rimba lestari, air terjun Sunggo Tuyo dusun Bulakkunci. Kelompok disini diwakili oleh beberapa komunitas yang ada didusun Bulakkunci diantaranya adalah kelompok Karang Taruna, Kelompok Ibu-ibu PKK dan Kelompok jamaah Yasin-Tahlil dusun Bulakkunci. Langkah awal adalah terciptanya kesadaran diantara mereka kemudian melakukan langkah kongkrit diantaranya dengan membersihkan tempat menuju lokasi air terjun, selanjutnya mencoba memperbaiki beberapa spot foto yang sudah rusak, membersihkan dan memperbaiki tempat shalat (Mushallah) yang sudah tidak layak pakai, serta memberikan papan nama dengan berbagai kata dan kalimat dengan tujuan membuat para pengunjung terhibur dan tertarik dan beberapa langkah lain yang tujuannya adalah menghidupkan kembali wisata air terjun Sunggo Tuyo dusun Bulakkunci. 
Dari beberapa upaya design (merencanakan) di atas setelah wisata Air terjun Songgo Toyo ini hidup maka selanjutnya adalah destiny (membangun perbaikan nasib) bagaimana komunitas ini terbantu dengan hadirnya wiasata air terjun ini yaitu dengan menjadikan wisata dusun Bulakkunci sekaligus mencari penghidupan dari hadirnya wisata air terjun ini diantaranya adalah dengan menjadikan wisata Air terjun Songgo Tuyo untuk dikembangkan menjadi wisata alam yang ada di desa Nogosari tepatnya dusun Bulakkunci selain itu hadirnya wisata ini bisa dijadikan sebagai sarana didalam menopang ekonomi masyarakat desa Nogosari dengan memberlakukan tiket masuk ke area air terjun Songgo Tuyo, serta mempersiakan lahan parkir untuk roda empat ataupun roda dua di area air terjun Songgo Tuyo, menjual minuman dan makanan di sekitar area air terjun Songgo Tuyo, masyarakat sekitar desa Nogosari bisa menjual makananan khas daerah Mojokerto, memberikan jasa untuk foto dan cetak foto, menyiapakan sewa baju bagi para pengunjung yang akan mandi dan berselvi di area air terjun serta beberapa hal lain yang bisa dilakukan oleh warga sekitar demi lestarinya wisata alam serta penopang ekonomi masyarakat sekitar desa Nogosari, Pacet, Mojokerto.

\section{Hasil dan Diskusi}

Pemberdayaan menurut bahasa berasal dari kata daya yang berarti tenaga/kekuatan, proses, cara, perbuatan memberdayakan.Pemberdayaan adalah upaya yang membangun daya masyarakat dengan mendorong, memotivasi dan membangkitkan kesadaran akan potensi yang dimiliki serta berupaya untuk mengembangkannya. ${ }^{9}$ Hartomo melanjutkan bahwasanya Pemberdayaan diarahkan guna meningkatkan ekonomi masyarakat secara produktif sehingga mampu menghasilkan nilai tambah yang tinggi dan pendapatan yang lebih besar. Ekonomi masyarakat adalah segala kegiatan ekonomi dan upaya masyarakat untuk memenuhi kebutuhan hidupnya yaitu sandang, pangan, papan, kesehatan dan pendidikan. Dengan demikian dapat dipahami bahwa pemberdayaan ekonomi masyarakat merupakan satu upaya untuk meningkatkan kemampuan atau potensi masyarakat dalam kegiatan ekonomi guna memenuhi kebutuhan hidup serta meningkatkan kesejahteraan mereka dan dapat berpotensi dalam proses pembangunan nasional. Konsep pemberdayaan lahir sebagai antitesis terhadap model pembangunan dan model industrialisasi yang kurang memihak pada rakyat mayoritas. Konsep ini dibangun dari kerangka logik sebagai berikut: (1) Bahwa proses pemusatan kekuasan terbangun dari pemusatan penguasaan faktor produksi; (2) Pemusatan kekuasaan faktor produksi akan melahirkan masyarakat pekerjaaan masyarakat yang pengusaha pinggiran; ${ }^{10}$ (3)

${ }^{9}$ I K Dewi, "Model Pengelolaan Kawasan Permukiman Berkelanjutan Di Daerah Aliran Sungai (DAS) Ciliwung Hulu Kabupaten Bogor" (Doctoral Dissertation, Institut Pertanian Bogor, 2010).

10 Hadimulyono M.B., "Kebijakan Pengeloaan Suberdaya Air Menurut Undang-Undang Tengtang Sumber Daya Air Dalam Perepesktif Menunjang Pembanguan Pertanian" (Bogor: Deptan Bogor, 2004). 
Kekuasaan akan membangun bangunan atas atau sistem pengetahuan, sistem politik, sistem hukum, dan ideologi yang manipulatif untukmemperkuat dan legitimasi; (4) Kooptasi sistem pengetahuan, sistem hukum, sistem politik, dan ideologi,secara sistematik akan menciptakan dua kelompok masyarakat, yaitu masyarakat berdaya dan masyarakat tunadaya. Akhirnya yang terjadi adalahdikotomi, yaitu masyarakat yang berkuasa dan manusia yang dikuasai. Untukmembebaskan situasi menguasai dan dikuasai, maka harus dilakukanpembebasan melalui proses pemberdayaan bagi yang dikuasai (empowerment of the powerless). ${ }^{11}$

Adapun yang perlu diejahwantahkan dalam kondisi ini yaitu tiga pilar diperhatikan dalam rangka pemberdayaan masyarakat. Ketiga pilar tersebut antara lain adalah pemerintah, swasta dan komunitas yang akan menjalin hubungan kemitraan yang selaras diantara mereka. Kemitraan ini nantinya diharapkan membentuk adanya kemandirian pada sebuah komunitas, kemandirian tersebut mulai dari kemandirian berfikir, kemandirian beraktifitas serta kemandirian apa yang mereka apa yang mereka perbuat demi kemaslahatan mereka. Pemberdayaan masyarakat hendanya mengarah pada pembentukan kognitif masyarakat yang lebih baik, sebab pmbentukan kognitif ini membutuhkan proses yang tidak sebentar. Pemberdayaan masyarakat tidak semudah membalikkan telapak tangan, oleh sebab itu ada dua upaya yang bisa dilakukan yang pertama membentuk masyarakat yang berwirausaha dan yang kedua dengan pendidikan. Semakin masyarakat gemar berwirausaha maka jalan kemandirian hidup di komunitas ini akan terbentuk, selanjutnya semakin banyak masyarakat yang berpendidikan maka semakin pula mereka akan menjadi insan yang kritis serta maju dalam bidang budaya dan ekonomi.

Selanjutnya dalam rangka pemberdayaan desa melalui wisata yang ada di komunitas kita sebagai pengabdi dengan langkah dream (membangun mimpi). Pada tahapan ini adalah lebih mengarah kepada bagaimana komunitas membangun mimpi mereka menuju kehidupan yang lebih maju. Dalam hal ini komunitas diharapkan secara kolektif mampu membangun mimpi mereka, mereka (komunitas) telah punya skala prioritas dari skala prioritas inilah digerakkan oleh mereka secara bersama-sama menuju kemandirian ekonomi seperti halnya wisata yang ada didesa Nogosari dusun Bulakkunci. Terkait hal ini dimulai dari langkah yang paling kecil diantaranya komunitas mulai melakukan beberpa pertemuan yang dimulai dari kelompok ibu-ibu PKK, bapak-bapk jamaah Yasin Tahlil, Adek-adek karang taruna, serte beberapa kelompok yang ada di dusun Bulakkunci. Dari kelompok ini, mereka (komunitas) memulai membersihkan menuju lokasi air terjun, selanjutnya mencoba memperbaiki beberapa spot foto yang sudah rusah, tempat shalat (Mushallah) yang sudah tidak layak pakai, serta memberikan papan nama dengan tujuan mempermudah para wisatawan menuju arah wisata, dimana semua sarana-prasarana yang sebelumnya sudah pernah

11 Mardi. Hutomo \& Yatmo, Pemberdayaan Masyarakat Dalam Bidang Ekonomi (Yogyakarta: Adiyana Press, 2000). 
ada dan eksis pada tiga tahun sebelumnya oleh masyarakat dusun Bulakkunci mulai diperbaharui. Adapun langkah ini sebagaimana gambar dibawah ini.
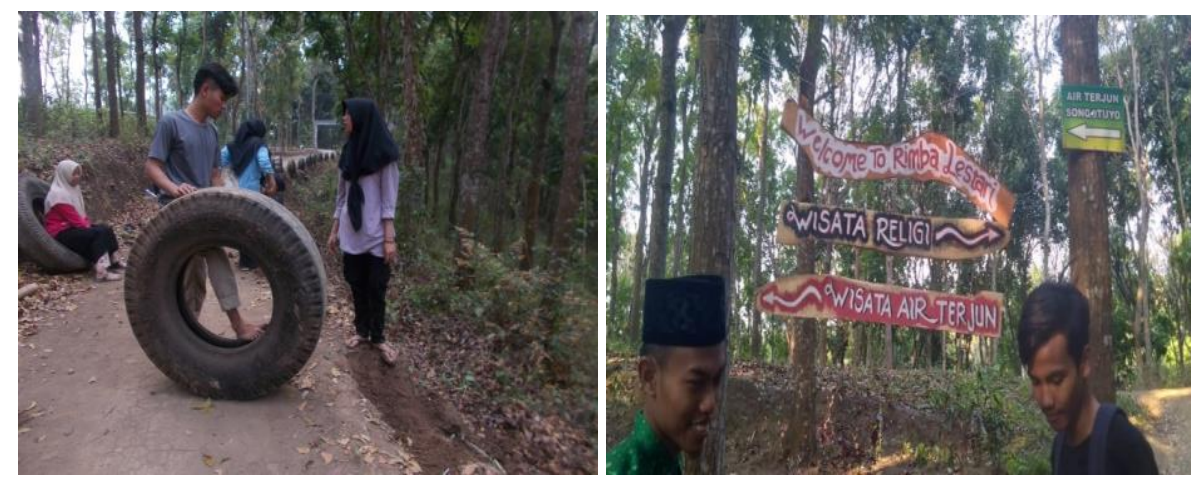

Gambar 2. Membersihkan area masuk ke Wisata (kiri) dan Menghiasi Area Masuk ke Wisata (kanan)
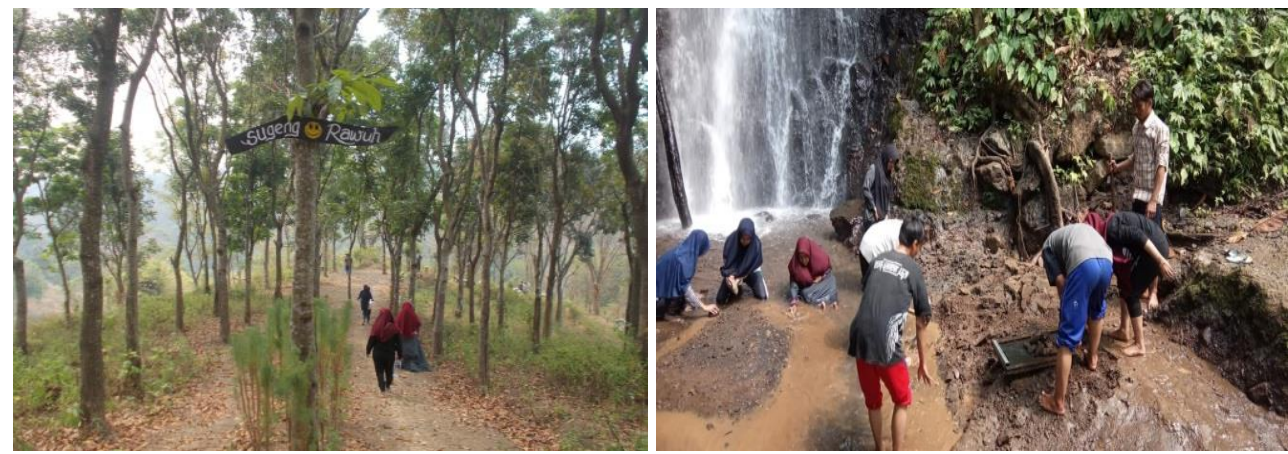

Gambar 3. Area Masuk ke wisata Air Terjun Songgo Tuyo (Kiri) Membersihkan Wisata Air Terjun (Kanan) ${ }^{12}$

Serasa tidak cukup rasanya kalau sebuah program pengabdian terhadap masyarakat yang dilakukan oleh dosen dan mahsiswa hanya sekedar membersihkan lokasi dampingan sebagai skala prioritas tanpa adanya follow up terhadap beberapa program yang telah dilaksanakan. Adapun yang menjadi target dari pengabdian ini adalah timbulnya rasa kesadaran dalam diri komunitas bahwasanya mereka (komunitas) mempunyai kekuatan yang perlu dijaga kelestariannya serta eksistensi dari kekuatan tersebut yang salah satunya adalah Ait terjun Songgo Tuyo. Berdasarkan tuturan dari kepala Bapak Polo dusun Bulakkunci bahwasanya wisata alam rimba lestari yaitu wisata air terjun songgo Tuyo pada awal pembabatannya ini ramai dikunjungi oleh para wisatawan. Namun seiring dengan berjalannya waktu di akibatkan oleh tidak adanya pengurus wisata yang betul-betul serius didalam penanganan wisata

12 Dokumentasi kegiatan masyarakat dusun Bulakunci desa Nogosari membersihkan area Wisata Alam Rimba, sebuah area menuju pemandiaan air terjun Sunggo Tuyo. 
tersebut, keberadaan wisata air terjun ini sudah sekian lama vakum dan tidak eksis lagi sebagaimana tiga tahun sebelumnya. ${ }^{13}$

Oleh sebab itu perlu kiranya media informasi dan promosi yang efektif demi eksisnya kembali wisata air terjun ini, mengingat adanya era saat ini bisa dikata sebagai sebuah era di mana hal-hal yang lama akan digantikan dengan hal-hal yang baru. Hadirnya tehnologi yang serba fisik (lama) digantikan dengan tehnologi digital yang menghasilkan sesuatu yang benar-benar baru serta lebih efisien dan lebih memberikan manfaat. Di era ini salah satu aplikasi yang digunakan adalah Internet dan aplikasi media sosial yang bisa digunakan oleh seorang user untuk menyebarkan informasi dan menerima informasi dari orang lain. Berdasrkan temuan yang dilaporkan oleh Asosiasi Penyelenggara Jasa Internet Indonesia (APJII) pada tahun 2018 kemarin bahwasanya pengguna internet di Indonesia ada sekitar 171, 17 juta pengguna. Berdasarkan segmen umur pengguna internet dari usia 15-19 tahun mencapai 91\%, pengguna pada kelompok usia 25-29 tahun dengan penetrasi 82,7\%, kelompok umur 30-34 tahun dengan penetrasi 76,5\% dan kelompok umur 35-39 tahun penetrasinya adalah 68,5\%. Berdasrkan data ini maka yang paling besar pengguna Internet adalah dari kelompok pemuda. ${ }^{14}$ Penggunaan internet dan media sosial sebagai media penyampai informasi tentunya ada dampak positif dan dampak negative. Adapun dampak positif yang didapat dengan hadirnya media ini adalah member ikan kemudahan bagi para user untuk mendapatkan pengetahuan dan informasi dengan mudah.

Salah satu informasi yang bisa diperoleh dengan mudah oleh seorang user adalah adanya lokasi wisata yang ada di sebuah daerah tertentu yang tidak cukup diketahui oleh masyarakat lokal namun hingga internasional. Arief Yahya selaku mentri Parawisata RI menyatakan bahwasanya lebih dari sekitar 300 juta orang yang mencari tempat-tujuan wisata di era ini dengan menggunakan internet, namun dari data 300 juta orang lebih itu hanya ada sekitar 80.000 orang yang mencari wisata di Indonesia, Berdasarkan data yang dinyatakan oleh bapak mentri Wisata ini berarti masih kurang dari saru persen dari penjelajah dunia yang mencari wisata di Indonesia. Bapak Arief Yahya menyatakan juga bahwasanya data pencarian wisata yang dilakukan oleh orangorang pada laman Google didominasi oleh pencarian wisata di Malasia. Menilik hal ini tentunya tentang eksistensi parawisata yang ada di Indonesia agar pemerintah setempat mendorong adanya percepatan pemasaran terkait wisata di Indonesia ini dengan melalui media Internet. Seperti halnya wisata diluar pulau Pacet yang telah dilakukan oleh tim pengabdi masyarakat yaitu dengan membuat web terkait keberadaan wisata di Gunung Kidul misalnya. Salah satu konsep baru yang dilakukan

13 Di ungkapkan oleh Kepala dusun Bulakkunci desa Nogosari Bapak Umar Faruq tentang keberadaan wisata air terjun Songgo Tuyo yang sudah vakum di akibatkan dominasi kelompok terhadap wisata tersebut pada tanggal 7 April 2019

14 Data ini bisa anda lihat pada

https://amp.kompas.com/tekno/read/2019/05/1603260037/apjii-jumlah pengguna internet di indonesiatembus171 jiwa 
oleh Tim Pengabdian Masyarakat adalah dengan E-Tourism. E-Tourism ini adalah sebuah konsep baru yang dikembangkan oleh berbagai kampus yang melakukan pendampingan kepada wisata sebagai wujud digitalisasi dalam mempromosikan wisata yang ada di masyarakat. Hadirnya E-Tourism diharapkan mampu menarik para wisatawan dua kali lipat dari sebelumnya hahingga mencapai 20 juta wisatawan mancanegarapada tahun 2019.15

Begitupun dengan keberadaan Wisata didesa Nogosari seperti halnya wisata yang masih satu desa yaitu wisata desa Panggang Puthuk Wellut yang menawarkan keindahan alam dengan berbagas spot foto didalamnya dan tidak bisa lepas dengan media online. Wisata alam rimba lestaripun demikian yaitu dengan memanfaatkan media online. Maka langkah awal yang dilakukan oleh tim pengabdi sekaligus peneliti dalam hal ini adalah dengan cara memetakan beberapa potensi, aset yang perlu dikembangkan demi menopang perekonomian masyarakat sekitar Bulakunci. ${ }^{16}$ Tentunya hal ini berdasrkan hasil dari FGD yang telah dilakukan oleh tim pengabdi dengan lapisan masyarakat dan struktur masyarakat dusun Bulakkunci. Dari hasil FGD yang telah dilakukan maka pemetaan aset pada pngembangan desa berbasis wisata yang dapat dipasarkan antara lain adalah:

\section{Wisata Alam Rimba Lestari}

Wisata alam rimba lestari yang ada di dusun Bulakkunci adalah pemandangan alam yang menyejukkan mata, ketika kita hadir ke alam rimba lestari ini, kita seakan di sajikan bermacam menu wista alam, diantaranya terdapat area Camping Ground, pohon pinus yang munjulang tinggi, dan beberapa spot foto dengan latar bebukitan yang indah serta jalan terjal trap yang terbuat dari ban bekas serta pemandian air terjun Songgo Tuyo.

\section{Wisata Kuliner}

Tidak menuntut kemungkinan adanya beberapa tempat wisata di Nogosari dusun Bulakkunci pun memberikan peluang kepada masyarakat sekitar dusun Bulakkunci untuk menjual makanan khas daerah mereka. Diantara makanan khas masyarakat dusun Bulakkunci yang menjadi ciri khas sekaligus sebagai wisata kuliner di daerah ini diantaranya adalah Onde-onde ala Mojokerto, Kerupuk Rambak, Kerupuk Upil, Sate Keong, serta makanan diantaranya Nasi Pecel ala Mojokerto, Nasi Sambel Wader, Es Gronjongan Majapahit, Es Cendol, Sinom, dan Nasi Rawon khas Mojokerto.

\footnotetext{
15 Rozaki and Rohaya, "Memberdayakan Desa Melalui Pariwisata Berbasis BUMDES ."

16 H.M. Jogiyanto, Analisis Dan Desain Sistem Informasi (Yogyakarta: Andi Offset, 1990).
} 


\section{Wisata Budaya}

Sebagai bangsa yang besar, Indonesia yang terdiri dari berbagai budaya merupakan modal pendukung untuk mencapai suksesnya pembangunan di desa, terutama sebagai modal dasar untuk mempromosikan diri desa dalam kancah persaingan tingkat lokal, daerah, nasional maupun internasional. Ada beberapa sumber daya sosial budaya di desa Nogosari yang kemudian dijadikan sebagai Wisata budaya di desa Nogosari. Berdasarkan hasil wawancara dengan masyarakat, bahwa ada beberapa budaya yang masih eksis di desa Nogosari ini diantaranya adalah Budaya Terbang Jidur, Budaya Bantengan, Budaya Malam tirakatan, Tradisi Grebeg Suro, Ujung, Ludruk, Wayang kuglit, Kuda lumping. Semua budaya ini terdokumentasi di kantor (Balai Desa) Nogosari Kecamatan Pacet Kabupaten Mojokerto dan bisa dilihat eksisitensi budaya ini salah satu budaya yang sering ditampilkan pada setiap acara di desa adalah budaya Terbang Jidur.

\section{Produk Merchandise}

Selanjutnya untuk menjadikan keberadaan wisata alam rimba lestari ini menjadi sebuah kekutan bagi masyarakat desa Nogosari dusun Bulakkunci maka Merchandisepun dijadikan media sebagai penopang perekonmian masyarakat dusun Nogosari. Sebelumnya, tim pendamping telah memberikan pelatihan kepada ibu-ibu untuk membuat souvenir yang terbuat dari Botol bekas. Begitup un dengan Produk Merchandise setelah mereka ulbu-ibu mendapat pelatihan dari peserta berupa pembuatan souvenir, pembuatan gantungan kunci, pembuatan piring dari botol bekas maka merekapun mencoba menjual produk merchandise kepada para wisatawan yang berkunjuang ke area wisalata alam rimba lestari. Seperti halnya di atas mereka para wisatawan bisa membeli mainan kunci khas Desa Nogosari, Gelas Cantik, Kaos yang bertuliskan keindahan wisata alam rimba lestari.

Dari beberapa aset wisata yang telah didiskripsikan di atas bahwasanya semua aset tersebut menjadi penopang akan eksisitensi wista air terjun Songgo Tuyo. Langkah selanjutnya (kedua) dalam pengabdian ini mencoba mendesain sistem wisata air terjun songgo tuyo yang terbagi menjadi dua tahap yaitu perencanaan secara konseptual dan perencaaan secara fisik. Perencanaan secara konseptual yang dilakukan oleh Tim pengabdi dalam hal ini dengan seringkali disebut sebagai perencanaan logis terkat bagaimana diskripsi wisata air terjun Songgo Tuyo serta beberapa aset lain yang menopang keberadaan aset ini. Media yang digunakan tim pengabdi Dalam hal ini dengan menggunakan media web dan media instagram. Selanjutnya untuk perencanaan fisik dalam tahap ini mencoba mendesain fisik area wisata dengan membuat skesta rancangn wisata air terjun hingga aset wisata lain yang menopang keberadaan wisata air terjun Songgo Tuyo ini.

Selanjutnya Implemementasi dari kedua perencanaan secara konseptual dan 
secara fisik. Implementasi dari kedua perencanaan ini yaitu dengan mempromosikan kehadiran wisata air terjun Songgo Tuyo ini kepada public dengan harapan setelah komunitas sadar bahwasanya wisata ini adalah aset dan kekuatan mereka maka bagaimana mereka (komunitas) membetuk sebuah kemitraan diantara mereka kemudian mempromosikan wisata air terjun Songgo Tuyo ini kepada public. Implemaantasi langkah ini dengan cara membuat kompetisi berselfi di area wisata air terjun Songgo Toyo. Terkait kompetisi berselfi ini oleh tim pengabdi dibuatkan pamphlet yang kemudian disebarkan melalui media sosial seperti melalui Facebook, Twiter, Instagram, WhatsAp dan lain-lain. Tentunya implementasi dari perencanaan di atas nantinya pun melibatkan beberap eleman aset wisata lain yang telah dipaparkan di atas $^{17}$ sehingga tujuan utamanya adalah menjadi kekutan bagi masyarakat dusun Bulakkunci. Gambar 4. Merupakan dokumentasi pamflet kompetisi berselfi di area wisata air terjun Songgo Tuyo.
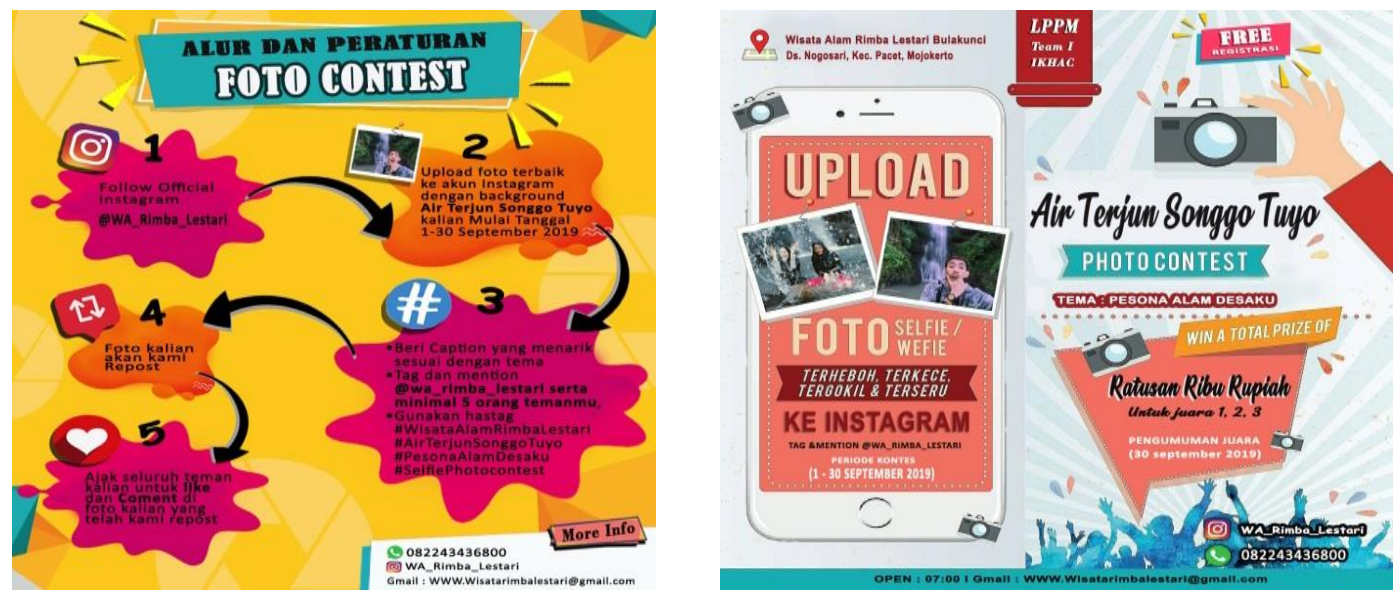

Gambar 4. Pamflet Kontes Foto Air Terjun Songgo Tuyo

Kompetisi yang diadakan ini menarik perhatian masyarakat luas dan ada sekitar enam puluh peserta yang berkompetisi mengikuti perlombaan kontes foto diwisata air terjun Songgo Tuyo ini. Dari enam puluh peserta panitia pelaksana kompetisi kontes foto mengumumkan tiga pemenang utama melalui media sosial melalui WhatsAp dan Instagram lewat akun yang tertera di pamphlet di atas.

Langkah yang keempat dalam pengabdian ini adalah pemeliharaan terhadap keberadaan wisata Air terjun Songgo Tuyo serta beberapa aset wisata lain yang menopang keberadaan eksistensi air terjun ini. Tahap setelah menciptakan kesadaran pada komunitas dan mengembalikan eksistensi wisata ini tidaklah semudah membalikkan telapak tangan. Oleh sebab itu langkah promosi secara online dan offline masih di praktikkan dalam pemeliharaan ini. Contoh pemeliharaan secara online oleh

${ }^{17}$ Adapun wisata lain yang menopang eksistensi wisata air terjun Songgo Tuyo antara lain adalah Wisata Alam Rimba Lestari, Wisata Kuliner dan Produk Merchandise 
struktural pengurus wisata air terjun yang biasanya ditangani oleh kelompok sadar wisata (POKDARWIS) namun pada realitanya lembaga desa ini belum ada, maka struktural pengurus wisatae ini senantiasa mempromosikan wisata yang ada di desa Nogosari ini yaitu dengan menggunakan media WhastAp dan Facebook. Sementara langkah pemeliharaan secara offline dilaksanakan oleh pengurus struktural wisata dengan membuat Baliho besar yang diletakkan di area arah masuk ke lokasi wisata.

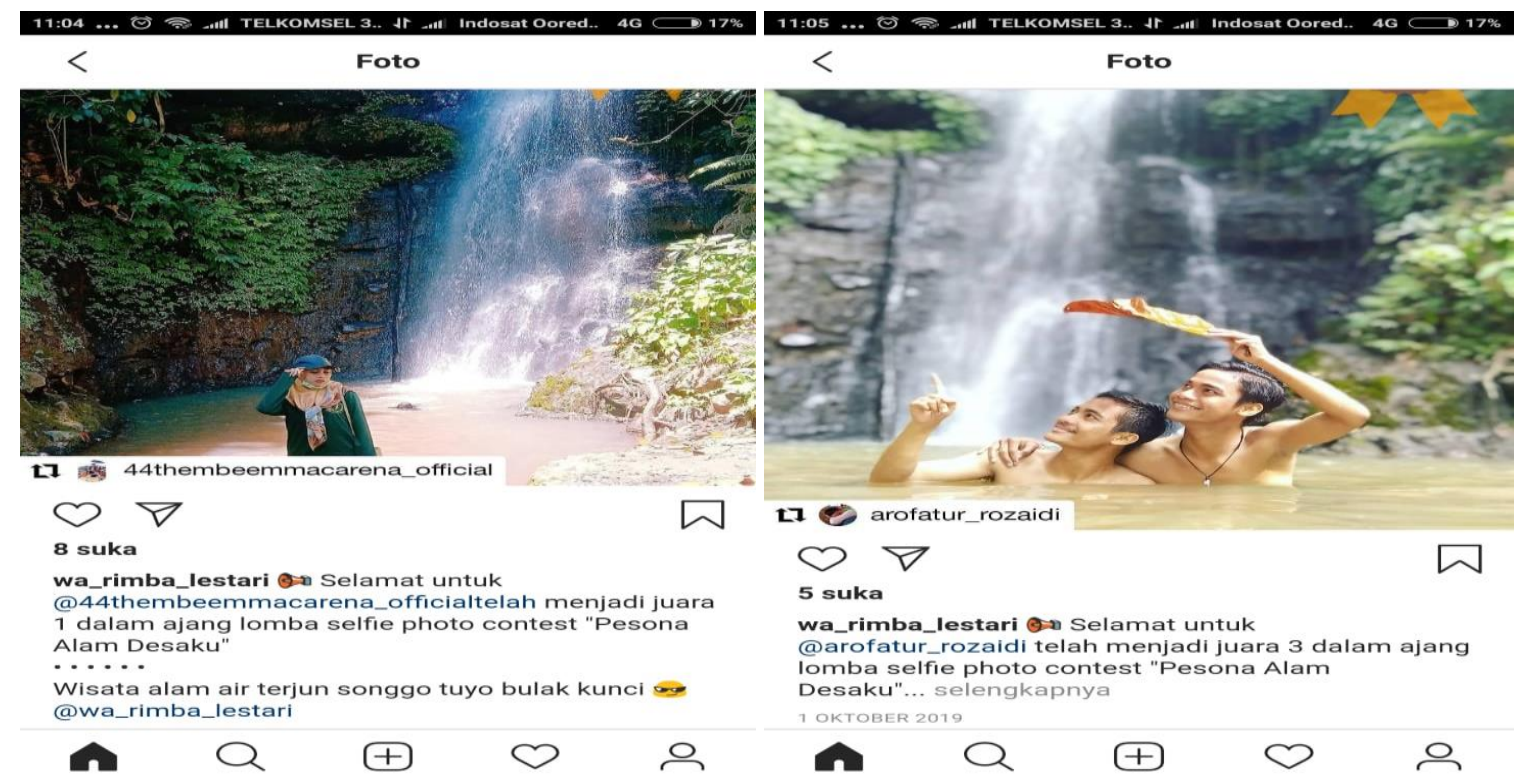

Gambar 5. Hasil Desain dan pemenang Lomba Pos Foto Air Terjun Songgo Tuyo

Adapun yang menjadi tujuan utama dari beberapa langkah di atas adalah untuk menjadikan wisata air terjun sebagai kekayaan alam rimba lestari adalah untuk menjadi sebuah brend parawisata yang nantinya dikenal oleh lapisan masyarakat dari lokal hingga internasional. Brand adalah merek sedangkan brending adalah kegiatan komunikasi yang dilakuakn oleh sebuah kelompok, perusahaan atau struktur pengelola aset wisata dengan tujuan membangun serta membesarkan brend atau merek pada perusahaan tersebut. Senada dengan makna di atas terkait branding sebagaimana dinyatakan oleh Kostler ${ }^{18}$ bahwa makna dari branding adalah pemberian sebuah nama, tanda, istilah, simbol, rancangan atupun kombinasi dari kesemuanya dibuat berdasarkan tujuan identifikasi barang ataupun jasa untuk membedakan dari barang atau jasa pesaing. Pada konteks ini adapun brending yang digunakan oleh tim pengamdian masyarakat bertujuan untuk menggaet para wisatawan didalam mengenal wisata air terjun Songgo Tuyo khususnya melalui media intenet. Selanjutnya dari desain keberadaan wisata ini mencoba mempegaruhi psikologi para user. Seorang user dalam

18 \& Kevin Lane Keller. Kotler, Philip, Manajemen Pemasaran (Jakarta: Erlangga, 2009). 
hal ini berdasasarkan paradigm psikologis ${ }^{19}$ yang didasarkan pada artian stimulusrespon langsung merespon secara positif akan eksistensi wisata air terjun Songgo Tuyo.

\section{Kesimpulan}

Berdasarkan penjelasan tersebut di atas, maka dapat disimpulkan bahwa setiap daerah mempunyai aset bisa dikembangkan melalui pengabdian kepada masyarakat, salah satunya wisata air terjun Songgo Tuyo. Dalam pengabdian dengan pendekatan ABA ini tim pendamping bersama masyarakat telah mengembangkan aset wisata air terjun dari semula tidak terkelola menjadi sebuah aset yang mampu menambah modal sosial pengembangan aset wisata desa melalui POKDARWIS. Tata kelola wisata air terjun ini mulai dilakukan mulai dari pemetaan aset, pengembangan dan revitalisasi aset, serta pemanfaatan media sosial dalam promosi. Hasil pengabdian masyarakat ini mampu mendorong warga sekitar wisata air terjuna Songgo Tuyo untuk berperan secara bersama-sama menjaga eksisitensi wisata dengan menggunakan media online ataupun offline untuk pengembangan wisata air terjun berbasis komunitas.

\section{Daftar Referensi}

Arifin, Anwar. Dakwah Kontemporer : Sebuah Studi Komunikasi. Jakarta: Graha Ilmu, 2011.

Cravens, David W. "Implementation Strategies in the Market-Driven Strategy Era." Journal of the Academy of Marketing Science 26, no. 3 (1998): 237-241.

Dewi, I K. "Model Pengelolaan Kawasan Permukiman Berkelanjutan Di Daerah Aliran Sungai (DAS) Ciliwung Hulu Kabupaten Bogor." Doctoral Dissertation, Institut Pertanian Bogor, 2010.

Hutomo \& Yatmo, Mardi. Pemberdayaan Masyarakat Dalam Bidang Ekonomi. Yogyakarta: Adiyana Press, 2000.

Jogiyanto, H.M. Analisis Dan Desain Sistem Informasi. Yogyakarta: Andi Offset, 1990.

KKN ABCD, UINSA. Panduan KKN ABCD UIN Sunan Ampel Surabaya. Cetakan ke. Surabaya: LP2M UIN Sunan Ampel Surabaya, 2015.

Kotler, Philip, \& Kevin Lane Keller. Manajemen Pemasaran. Jakarta: Erlangga, 2009.

M.B., Hadimulyono. “Kebijakan Pengeloaan Suberdaya Air Menurut Undang-Undang Tengtang Sumber Daya Air Dalam Perepesktif Menunjang Pembanguan Pertanian." Bogor: Deptan Bogor, 2004.

Mathie, Alison, and Gord Cunningham. "From Clients to Citizens: Asset-Based Community Development as a Strategy for Community-Driven Development." Development in practice 13, no. 5 (2003): 474-486.

Nurdiyanah dkk. Panduan Pelatihan Dasar : Asset Based Community-Driven Development

${ }^{19}$ Anwar. Arifin, Dakwah Kontemporer : Sebuah Studi Komunikasi (Jakarta: Graha Ilmu, 2011). 
$(A B C D)$. Makasar: , Seri Publikasi Kemitraan Universitas - masyarakat UIN Alaudin Makkasar, Cetakan 1, 2016.

Paul Green, Garry and, Hanis, Anna. Asset Building Community Development. USA: Sage Publication, 2001.

Rozaki, Abdur, and Siti Rohaya. "Memberdayakan Desa Melalui Pariwisata Berbasis BUMDES ." Engagement: Jurnal Pengabdian Kepada Masyarakat 3, no. 1 SE-Articles (May 30, 2019).

http://engagement.fkdp.or.id/index.php/engagement/article/view/46.

Sudarmadi, Tular. "Pengembangan Potensi Kepariwisataan Berbasis Masyarakat Di Desa Pengkol, Kabupaten Sukoharjo, Jawa Tengah.” Bakti Budaya 1, no. 1 (2018): 73-91.

Zamroni, Sunaji. Desa Mengembangkan Sumber Penghidupan Berkelanjutan. Yogyakarta: IRE, 2015. 